\title{
Pengaruh Pemakaian Tipe Kaca pada Bangunan Gedung Terhadap Beban Pendingin dengan Menggunakan Software Hap Versi 4.90
}

\author{
Maryadi \\ Program Studi Teknik Mesin, Fakultas Sains dan Teknologi, \\ Universitas Islam As-Syafi'iyah. \\ Jl. Raya Jatiwaringin No. 12 Pondok Gede, Jakarta Timur 13070 \\ E-mail: adimaryadi77@yahoo.com
}

\begin{abstract}
Abstrak - Sesuai perkembangan jaman banyak sekali bangunan gedung bertingkat yang dibangun. Untuk memberi kenyamanan pengguna, bangunan gedung tersebut biasa dilengkapi dengan pendingin ruangan. Pendingin ruangan merupakan peralatan pada bangunan gedung yang memiliki kebutuhan listrik yang sangat besar, sekitar 60\% dari kebutuhan listrik total gedung untuk mensuplai sistem pendingin. Dengan tujuan untuk mengetahui kebutuhan beban pendingin yang dipengaruhi oleh U-value dan shade coeffetion pada kaca tipe bronze tint dan clear low e dengan variasi ketebalan $3 \mathrm{~mm}, 5 \mathrm{~mm}$ dan $6 \mathrm{~mm}$. Penggunaan tipe kaca pada bangunan gedung sangat berpengaruh terhadap perhitungan beban pendingin dan berpengaruh juga dengan pemakaian listrik, karena tebal kaca dan tingkat kecerahan kaca akan meneruskan panas yang berbeda - beda. Untuk mendapatkan hasil sesuai tujuan di atas, maka metode yang digunakan adalah dengan studi literatur dari berbagai sumber, mengumpulkan data berupa gambar denah arsitek, luas dinding, jenis kaca, luas kaca dan arah mata angin. Selanjutnya data tersebut diinput ke software HAP 4.90, sehingga akan didapatkan seberapa besar kebutuhan beban pendinginnya. Sesuai dengan hasil perhitungan didapatkan untuk kedua tipe kaca antara bronze tint dan clear low e didapatkan U-value dan Shade coeffetion yang lebih kecil dengan tipe kaca bronze tint pada parameter ketebalan kaca yang sama. Sehingga didapatkan kapasitas mesin pendingin dan air flow yang lebih kecil dengan tipe kaca bronze tint. Dengan nilai $U$-value dan shade coeffetion yang semakin kecil, maka akan didapatkan seleksi mesin pendingin yang mempunyai kapasitas lebih kecil.
\end{abstract}

Kata kunci: pendingin, kaca, U-value, shade coeffetion, gedung.

\section{Pendahuluan}

Pada saat ini penggunaan mesin pendingin ruangan sudah merupakan kebutuhan wajib, antara lain untuk gedunggedung perkantoran, apartemen, hotel dan mall. Dengan semakin tingginya tingkat kebutuhan manusia untuk mendapatkan kenyamanan pada saat bekerja ataupun beristirahat. Kenyamanan yang berupa temperatur, kelembaban dan hembusan udara yang sesuai dengan lingkungan sekitar akan tercapai apabila mesin pendingin yang dipasang sesuai dengan beban dari sebuah ruangan tersebut. Sehingga pada saat sekarang ini banyak perkembangan dan kemajuan mesin pengkondisian udara. [1].

Kondisi udara ruangan yang direncanakan harus sesuai dengan fungsi dan persyaratan penggunaan ruangan yang dimuat dalam standar. Menurut SNI 6390:2011 mengenai Konservasi Energi Sistem Tata Udara Bangunan Gedung, untuk memenuhi kenyamanan termal penghuni bangunan, kondisi perencanaan gedung yang berada di wilayah dataran rendah atau pantai dengan suhu udara maksimum rata-rata sekitar $34^{\circ} \mathrm{C}$ DB dan $28^{\circ} \mathrm{C}$ WB atau suhu rata-rata bulanan sekitar $28^{\circ} \mathrm{C}$. Ditetapkan bahwa ruang kerja temperatur bola kering berkisar antara $24^{\circ} \mathrm{C}$ hingga $27^{\circ} \mathrm{C}$ atau $25,5^{\circ} \mathrm{C}$ plus minus $1,5^{\circ} \mathrm{C}$ dengan kelembaban relatif $60 \%$ plus minus $5 \%$. Sedangkan ruang transit seperti lobi, koridor temperatur bola kering berkisar antara $27^{\circ} \mathrm{C}$ hingga $30^{\circ} \mathrm{C}$ atau $28,5^{\circ} \mathrm{C}$ plus minus $1,5^{\circ} \mathrm{C}$ dengan kelembaban relatif $60 \%$ plus minus $10 \%$. [2], [3], [4], [5]

Mesin pendingin ruangan merupakan peralatan pendukung pada bangunan gedung yang mengonsumsi kebutuhan listrik yang sangat tinggi, kurang lebih $60 \%$ kebutuhan listrik pada bangunan gedung dibutuhkan untuk mesin pendingin ruangan. Maka dari itu dibutuhkan perhitungan beban pendingin yang sesuai dengan kebutuhan dan fungsi ruangan, sehingga pemakaian daya listrik tidak terlalu boros dan sesuai dengan kebutuhan. Untuk mendapatkan hasil seleksi mesin pendingin yang sesuai dibutuhkan data-data bangunan gedung, diantaranya tipe kaca yang digunakan, jumlah orang, fungsi ruangan dan beban panas yang ditimbulkan dari peralatan listrik.

Pemakaian kaca pada dinding bangunan gedung perkantoran menimbulkan beban panas yang sangat besar, sehingga kebutuhan mesin pendingin menjadi lebih besar. Pada saat sekarang ini sudah banyak sekali tipe berbagai jenis kaca yang bisa mengurangi pancaran sinar matahari yang mengenai dinding bangunan. Pemilihan jenis kaca 
yang tepat akan mengurangi pemakaian daya listrik yang di akibatkan oleh mesin pendingin yang seleksinya terlalu besar.

\section{Dasar Teori}

Pada dasarnya secara alami perpindahan panas terjadi dengan sendirinya dari daerah yang bertemperatur tinggi menuju ke daerah yang bertemperatur lebih rendah. Panas merupakan salah satu bentuk energi sehingga tidak dapat diciptakan atau dimusnahkan, namun dapat dipindahkan dari suatu tempat ke tempat yang lain. Proses terjadinya perpindahan panas merupakan sebuah fenomena alam antara dua zat atau lebih yang mempunyai perbedaan temperatur, sehingga secara alami zat - zat tersebut akan menyamakan temperaturnya untuk mencapai sebuah kesetimbangan.

Dalam suatu proses terjadinya perpindahan panas dapat mengakibatkan terjadinya perubahan temperatur atau perubahan tekanan pada suatu zat. Ada tiga mekanisme perpindahan panas antara lain perpindahan panas secara konduksi, perpindahan panas secara konveksi dan perpindahan panas secara radiasi.

\subsection{Perpindahan Panas Konduksi}

Perpindahan panas konduksi adalah perpindahan panas melalui zat padat, proses perpindahan panas secara konduksi bukan perpindahan zat tersebut melainkan sebuah proses perpindahan panasnya saja. Laju perpindahan panas merupakan nilai perpindahan panas tersebut, yang dirumuskan dengan panas yang mengalir persatuan waktu. Laju perpindahan panas secara konduksi merupakan perkalian antara konduktivitas panas dengan luas penampang dan selisih temperatur di kedua titik dibagi dengan jarak kedua titik. [6]

$$
q_{k}=k A \frac{d T}{\mathrm{dr}}
$$

dimana:

$\mathrm{q}=$ laju perpindahan panas konduksi $(\mathrm{W})$

$\mathrm{k}=$ konduktifitas thermal beban $(\mathrm{W} / \mathrm{m} \mathrm{K})$

$\mathrm{A}=$ luas penampang tegak lurus arah perpindahan panas $(\mathrm{m})$

$\mathrm{dT} / \mathrm{dr}=$ laju perubahan temperatur $\mathrm{T}$ terhadap jarak dalam arah aliran $r$ [7], [8]

\subsection{Perpindahan Panas Konveksi}

Perpindahan panas secara konveksi terjadi bila panas bergerak dari suatu tempat ke tempat lain melalui suatu aliran arus dalam medium liquid atau gas. Bila ada bagian fluida yang mendapat energi panas akan mengembang volume per satuan masa meningkat. Bagian fluida yang mendapat energi panas akan lebih ringan sehingga bergerak naik ke puncak dan ruang yang ditinggalkannya akan langsung diganti oleh fluida yang lebih ringan. Nilai kalor yang dipindahkan melalui konveksi dapat menggunakan persamaan berikut:

$$
q_{c}=h_{c} A\left(T_{s}-T_{\infty}\right)
$$

dimana:

$$
\begin{aligned}
& \mathrm{q}_{\mathrm{c}}=\text { kalor yang dipindahkan }(\mathrm{W}) \\
& \mathrm{h}=\text { koefisien pindah panas konveksi }\left(\mathrm{W} / \mathrm{m}^{2} \mathrm{~K}\right) \\
& \mathrm{A}=\text { luas permukaan dinding }\left(\mathrm{m}^{2}\right) \\
& \left(\mathrm{T}_{\mathrm{s}}-\mathrm{T}_{\infty}\right)=\text { perbedaan suhu dinding dengan suhu } \\
& \text { fluida }(\mathrm{K})
\end{aligned}
$$

Perpindahan panas konveksi dapat dibedakan menjadi dua yaitu konveksi bebas dan konveksi paksa. Konveksi bebas adalah perpindahan panas yang terjadi dimana aliran fluida bergerak dengan pengaruh gravitasi tanpa pengaruh eksternal yang lain. Sedangkan konveksi paksa adalah proses perpindahan panas dimana fluida bergerak dengan disengaja dan diatur kecepatan dan debitnya. Berdasarkan jenis aliranya konveksi dapat dibagi menjadi dua, yaitu konveksi pada aliran laminer dan konveksi pada aliran turbulen. [9]

Perpindahan panas konveksi pada pipa dipengaruhi oleh bilangan Reynold yang dapat dicari dengan persamaan berikut:

$$
R e=\frac{V D}{v}
$$

Angka Reynold digunakan untuk menunjukkan kriteria apakah aliran dalam pipa lamiar atau turbulen maka untuk menentukan kriteria itu dapat di jabarkan sebagai berikut:

-Bila $\operatorname{Re}<2300$ aliran tersebut dinamakan laminar -Bila $2300<\operatorname{Re}<4000$ aliran tersebut dinamakan transisi -Bila Re>4000 aliran tersebut dinamakan turbulen

\subsection{Perpindahan Panas Radiasi}

Perpindahan panas radiasi adalah proses perpindahan panas melalui gelombang elektromagnetik yang dapat merambat sampai jarak sangat jauh tanpa memerlukan interaksi dengan media. [10]

Perpindahan panas dengan radiasi dapat dirumuskan sebagai berikut:

$$
\mathrm{q}_{\mathrm{r}}=\sigma \cdot \mathrm{A} \cdot \mathrm{T}^{4}
$$

dimana:

$$
\begin{aligned}
& \sigma=\text { konstanta Stefen Boltzman }\left(5.67 \times 10^{-6} \mathrm{~W} / \mathrm{m}^{2}\right. \\
& \left.\quad \mathrm{K}^{4}\right) \\
& \mathrm{A}=\text { luas penampang }(\mathrm{m}) \\
& \mathrm{T}=\text { temperatur }(\mathrm{K}) \\
& \mathrm{q}_{\mathrm{r}}=\text { radiasi panas }(\mathrm{W})
\end{aligned}
$$

\section{Metodologi Penelitian}

Sistematika penelitian merupakan suatu diagram alir yang digunakan dalam proses penelitian. Adapun sistematika penelitian yang berjudul "Pengaruh Pemakaian Tipe Kaca Pada Bangunan Gedung Terhadap Beban Pendingin Dengan Menggunakan Software HAP Versi 4.90" berdasarkan tahapan dalam diagram alir sebagai berikut : 


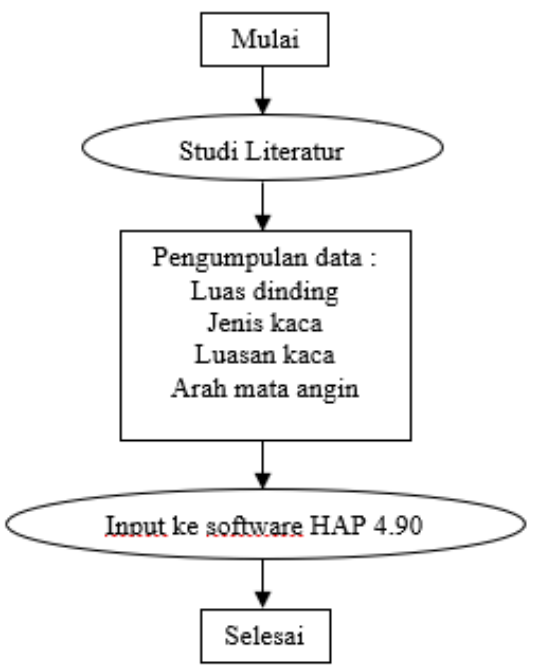

Gambar 1 Diagram Alir Proses Penelitian.

\subsection{Studi Literatur}

Studi literatur dapat dilakukan dengan mengumpulkan semua data yang berhubungan dengan penggunaan jenis kaca, dinding dan arah bangunan yang digunakan pada sebuah bangunan gedung. Hal ini bertujuan untuk mendapatkan informasi yang berguna untuk perhitungan ini. Informasi dapat ditemukan dari internet, jurnal penelitian, buku dan konsultan perencana.

\subsection{Pengumpulan Data}

Dari tahap studi literatur akan mendapatkan data data yang bisa diolah untuk perhitungan masukan ke program. Data - data arah bangunan yang dibutuhkan adalah bangunan menghadap kearah timur, barat, selatan atau utara bisa didapatkan dari denah arsitek. Biasanya konsultan arsitek akan memberikan informasi mengenai arah bangunan yang akan digunakan pada sebuah bangunan gedung.

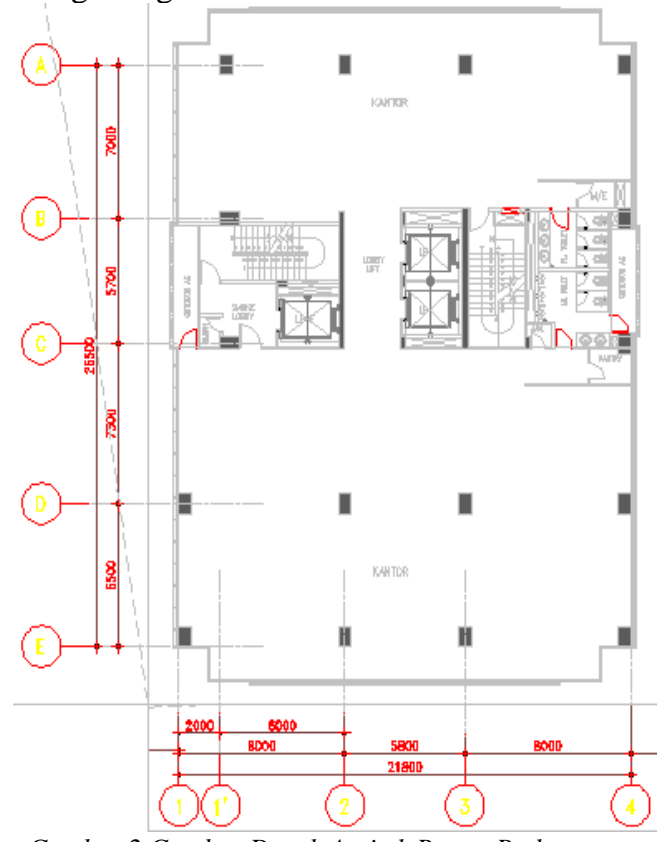

Gambar 2 Gambar Denah Arsitek Ruang Perkantoran.

\subsection{Perhitungan}

Untuk perhitungan beban pendingin menggunakan software HAP 4.90. Dengan memasukan data - data diantaranya jenis kaca, tebal kaca, luas kaca dan arah mata angin yang digunakan ke software tersebut, maka akan didapatkan kapasitas beban pendingin yang dibutuhkan dan pengaruh dari penggunaan arah mata angin dan data lainnya yang digunakan terhadap kapasitas beban pendingin. Arah mata angin pada bangunan gedung sangat berpengaruh terhadap kapasitas beban pendingin ruangan, karena jumlah panas sinar matahari yang masuk ke dalam bangunan gedung tergantung dari arah bangunan dan dinding bangunan yang digunakan. Semakin banyak panas sinar matahari yang masuk, berarti kaca yang digunakan hanya sedikit memantulkan panas sinar matahari, sehingga membutuhkan kapasitas beban pendingin ruangan yang lebih besar untuk melawan panas tersebut. Begitu juga sebaliknya semakin sedikit panas sinar matahari yang masuk, berarti kaca tersebut banyak memantulkan panas sinar matahari, sehingga kapasitas beban pendingin ruangan yang dibutuhkan lebih kecil untuk melawan panas tersebut.

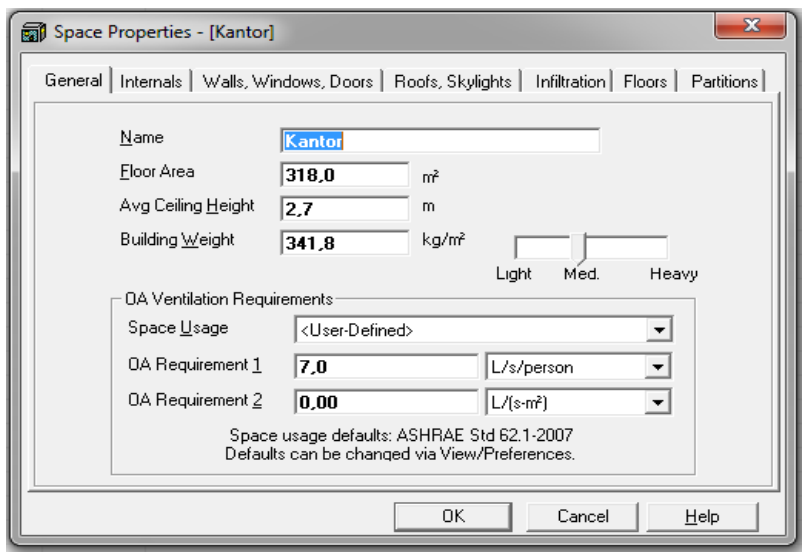

Gambar 3 Tampilan Software HAP 4.90 untuk Luas Ruangan

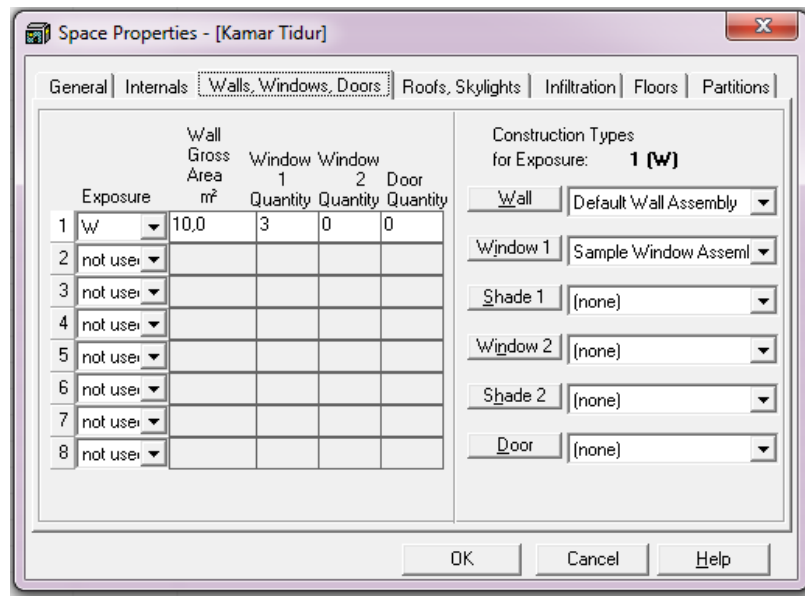

Gambar 4 Tampilan Software HAP 4.90 untuk Luas dinding. 


\section{Temuan dan Pembahasan}

Tabel dibawah adalah hasil dari perhitungan beban pendingin dengan menggunakan data beberapa jenis kaca yang berbeda. Terlihat bahwa pada tipe kaca yang mempunyai tebal kaca sama cenderung mempunyai nilai U-value yang sama, akan tetapi untuk nilai shade coeffetion cenderung berbeda. Semakin tebal tipe kaca cenderung nilai U-value semakin kecil sedangkan nilai shade coeffetion semakin turun juga.

Secara umum kaca dengan tingkat ketebalan yang tipis dan berwarna bening sudah pasti akan meneruskan panas sinar matahari menuju ke dalam bangunan gedung. Berbeda dengan kaca yang tebal atau berjajar lebih dari satu dan berwarna gelap akan sedikit meneruskan panas sinar matahari. Sehingga berpengaruh juga terhadap perhitungan beban pendinginnya.

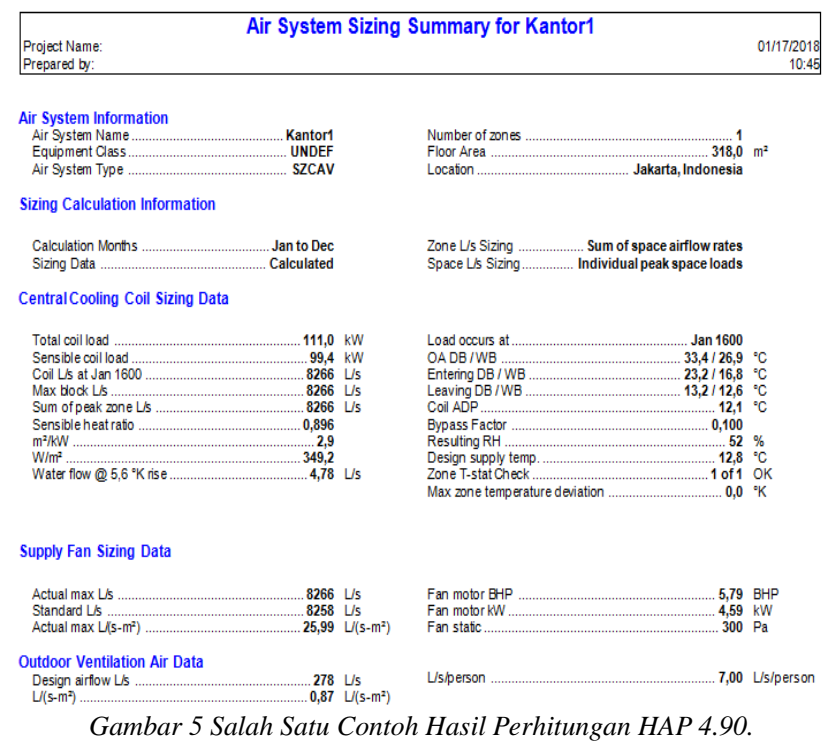

Tabel 1 Hasil Perhitungan Menggunakan Software HAP 4.90 untuk UValue dan Shade Coeffetion.

\begin{tabular}{|c|c|c|c|c|}
\hline No. & Tipe Kaca & $\begin{array}{c}\text { Tebal } \\
(\mathrm{mm})\end{array}$ & $\begin{array}{c}\text { U-Value } \\
\left(\mathrm{W} / \mathrm{m}^{2}\right. \\
\mathrm{K})\end{array}$ & $\begin{array}{c}\text { Shade } \\
\text { Coeffetio } \\
\mathrm{n}\end{array}$ \\
\hline 1 & Bronze Tint & 3 & 6,302 & 0,827 \\
\hline 2 & Bronze Tint & 5 & 6,235 & 0,741 \\
\hline 3 & Bronze Tint & 6 & 6,195 & 0,702 \\
\hline 4 & Clear Low E & 3 & 6,310 & 0,867 \\
\hline 5 & Clear Low E & 5 & 6,235 & 0,833 \\
\hline 6 & Clear Low E & 6 & 6,195 & 0,807 \\
\hline
\end{tabular}

Untuk tipe kaca bronze tint dari tebal 3, 5 dan $6 \mathrm{~mm}$ didapatkan besaran U-value 6,302, 6,235 dan 6,195 W/m² $\mathrm{K}$ dan shade coeffetion $0,827,0,741$ dan 0,702 . Ini berarti pada tipe kaca bronze tint semakin tebal kaca maka nilai U-value dan shade coeffetion semakin rendah. Sedangkan tipe kaca clear low e dari tebal 3, 5 dan $6 \mathrm{~mm}$ didapatkan besaran U-value 6,310, 6,235 dan 6,195 W/m² $\mathrm{K}$ dan shade coeffetion $0,867,0,833$ dan 0,807 . Ini berarti pada tipe kaca clear low e semakin tebal kaca maka nilai U-value dan shade coeffetion semakin rendah. Sehingga pada kedua jenis tipe kaca tersebut semakin tebal kaca maka nilai Uvalue dan shade coeffetion semakin rendah.gambar, grafik, diagram, dan skema harus diletakkan seperti pada contoh di bawah ini.

Tabel 2 Hasil Perhitungan Menggunakan Software E-20 untuk Total Cooling dan Air Flow.

\begin{tabular}{|c|c|c|c|c|}
\hline No. & Tipe Kaca & $\begin{array}{c}\text { Tebal } \\
(\mathrm{mm})\end{array}$ & $\begin{array}{c}\text { Total } \\
\text { Cooling } \\
(\mathrm{kW})\end{array}$ & $\begin{array}{c}\text { Air Flow } \\
(\mathrm{l} / \mathrm{s})\end{array}$ \\
\hline 1 & Bronze Tint & 3 & 110,8 & 8266 \\
\hline 2 & Bronze Tint & 5 & 105,3 & 7773 \\
\hline 3 & Bronze Tint & 6 & 103,0 & 7552 \\
\hline 4 & Clear Low E & 3 & 114,9 & 8490 \\
\hline 5 & Clear Low E & 5 & 111,0 & 8280 \\
\hline 6 & Clear Low E & 6 & 110,2 & 8126 \\
\hline
\end{tabular}

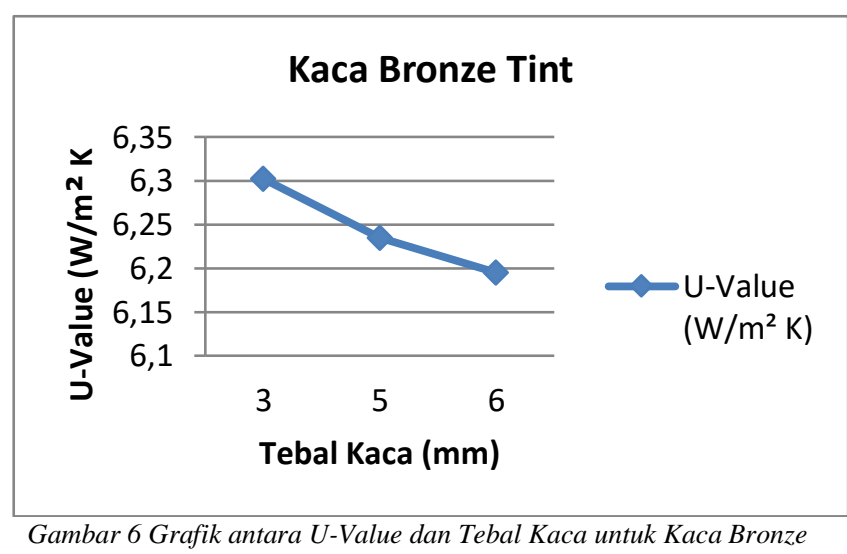

Tint.

Sesuai grafik di gambar 6 merupakan grafik untuk kaca bronze tint, grafik tersebut menggambarkan hasil perhitungan dari software antara U-Value dan tebal kaca, pada grafik tersebut tergambarkan bahwa semakin tebal kaca maka akan didapatkan nilai U-Value yang semakin kecil. Jadi pada jenis kaca bronze tint ini semakin tebal kacanya mempunyai transfer panas semakin kecil, sehingga panas yang masuk melewati kaca tersebut semakin kecil seiring dengan bertambahnya tebal kaca. Maka akan didapatkan perhitungan beban pendingin yang lebih kecil dibandingkan dengan menggunakan kaca yang lebih tipis. Hasil dari perhitungan beban pendingin yang lebih kecil tersebut merupakan dasar untuk seleksi mesin pendingin yang akan dipasang pada sebuah bangunan gedung, sehingga seleksi mesin pendingin yang kecil akan menghemat pemakaian daya listriknya. 


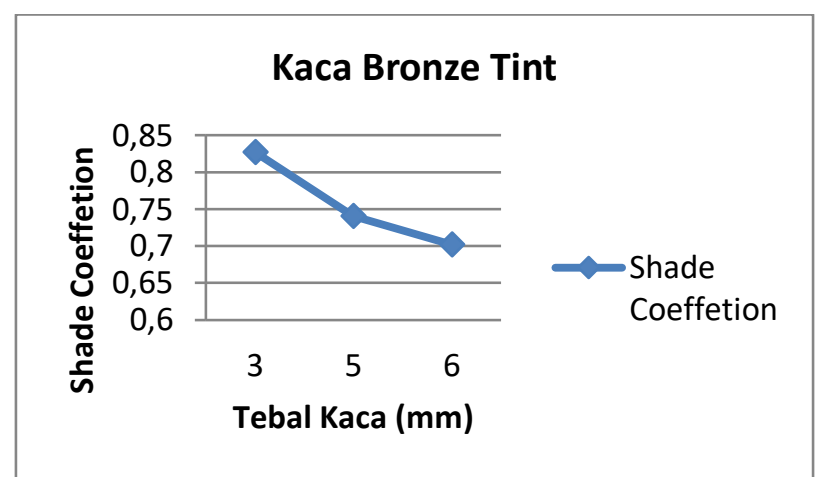

Gambar 7 Grafik antara Shade Coeffetion dan Tebal Kaca untuk Kaca Bronze Tint.

Berdasarkan grafik di gambar 7 merupakan grafik untuk kaca bronze tint, grafik tersebut menggambarkan hasil perhitungan dari software antara shade coeffetion dan tebal kaca, pada grafik tersebut tergambarkan bahwa semakin tebal kaca maka akan didapatkan nilai shade coeffetion yang semakin kecil. Jadi pada jenis kaca bronze tint ini semakin tebal kacanya mempunyai koefisien bayangan semakin kecil, sehingga cahaya yang masuk melewati kaca tersebut semakin kecil seiring dengan bertambahnya tebal kaca. Maka akan didapatkan perhitungan beban pendingin yang lebih kecil dibandingkan dengan menggunakan kaca yang lebih tipis. Hasil dari perhitungan beban pendingin yang lebih kecil tersebut merupakan dasar untuk seleksi mesin pendingin yang akan dipasang pada sebuah bangunan gedung, sehingga seleksi mesin pendingin yang kecil akan menghemat pemakaian daya listriknya.

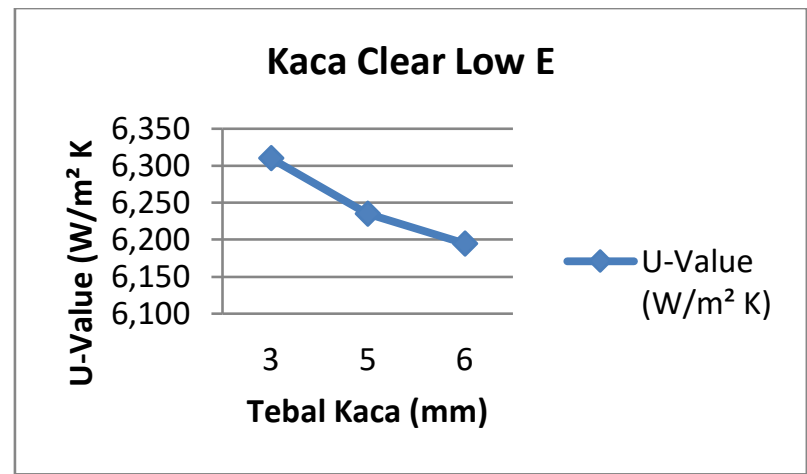

Gambar 8 Grafik antara U-Value dan Tebal Kaca untuk Kaca Clear Low E.

Sesuai grafik di gambar 8 merupakan grafik untuk kaca clear low e, grafik tersebut menggambarkan hasil perhitungan dari software antara U-Value dan tebal kaca, pada grafik tersebut tergambarkan bahwa semakin tebal kaca maka akan didapatkan nilai U-Value yang semakin kecil. Jadi pada jenis kaca clear low e ini semakin tebal kacanya mempunyai transfer panas semakin kecil, sehingga panas yang masuk melewati kaca tersebut semakin kecil seiring dengan bertambahnya tebal kaca. Maka akan didapatkan perhitungan beban pendingin yang lebih kecil dibandingkan dengan menggunakan kaca yang lebih tipis. Hasil dari perhitungan beban pendingin yang lebih kecil tersebut merupakan dasar untuk seleksi mesin pendingin yang akan dipasang pada sebuah bangunan gedung, sehingga seleksi mesin pendingin yang kecil akan menghemat pemakaian daya listriknya.

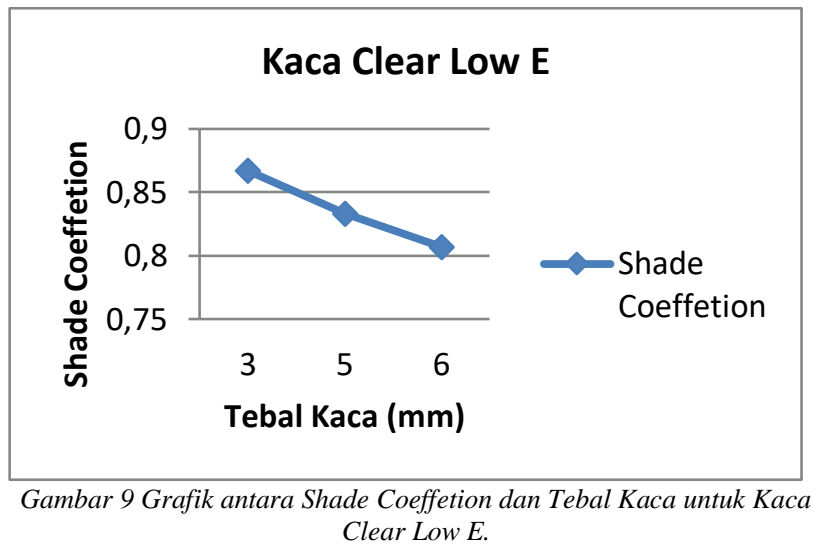

Berdasarkan grafik di gambar 9 merupakan grafik untuk kaca clear low e, grafik tersebut menggambarkan hasil perhitungan dari software antara shade coeffetion dan tebal kaca, pada grafik tersebut tergambarkan bahwa semakin tebal kaca maka akan didapatkan nilai shade coeffetion yang semakin kecil. Jadi pada jenis kaca clear low e ini semakin tebal kacanya mempunyai koefisien bayangan semakin kecil, sehingga cahaya yang masuk melewati kaca tersebut semakin kecil seiring dengan bertambahnya tebal kaca. Maka akan didapatkan perhitungan beban pendingin yang lebih kecil dibandingkan dengan menggunakan kaca yang lebih tipis. Hasil dari perhitungan beban pendingin yang lebih kecil tersebut merupakan dasar untuk seleksi mesin pendingin yang akan dipasang pada sebuah bangunan gedung, sehingga seleksi mesin pendingin yang kecil akan menghemat pemakaian daya listriknya.

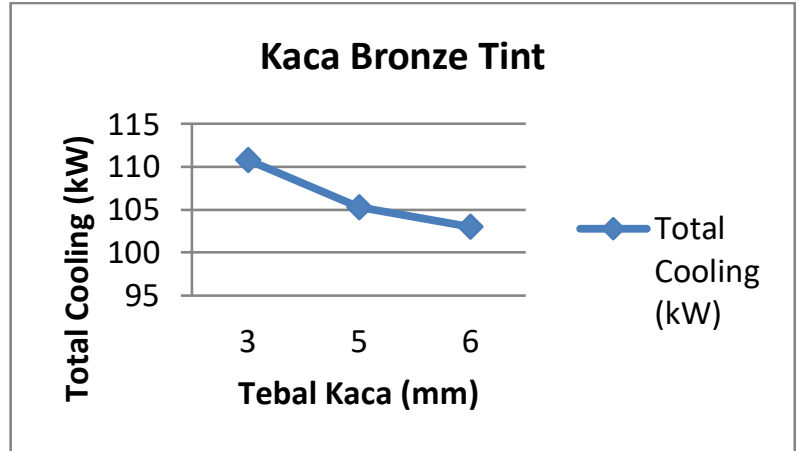

Gambar 10 Grafik antara Total Cooling dan Tebal Kaca untuk Kaca Bronze Tint.

Sesuai grafik di gambar 10 antara total cooling dan tebal kaca untuk kaca bronze tint, total cooling akan turun seiring dengan ketebalan kaca yang semakin bertambah. Ini berarti pada tipe kaca bronze tint semakin tebal kaca maka nilai U-value, shade coeffetion dan total cooling semakin rendah. Sehingga kebutuhan kapasitas mesin pendingin untuk gedung akan semakin rendah seiring dengan turunnya total cooling. 


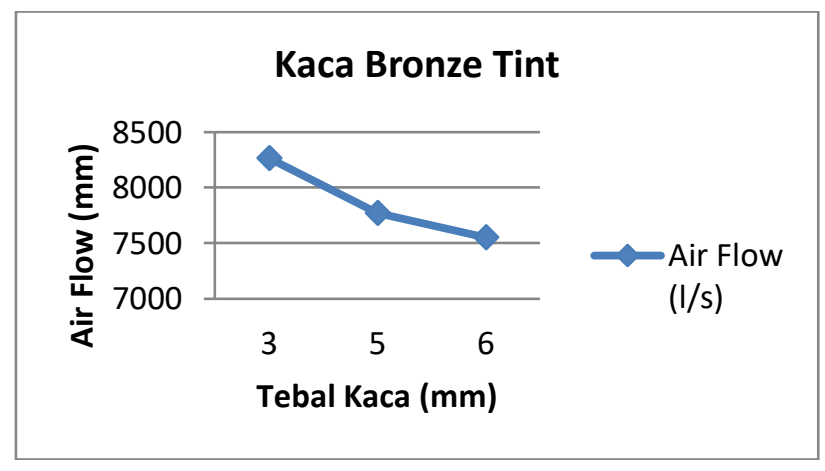

Gambar 11 Grafik antara Air Flow dan Tebal Kaca untuk Kaca Bronze Tint.

Berdasarkan grafik di gambar 11 antara air flow dan tebal kaca untuk kaca bronze tint, air flow akan turun seiring dengan ketebalan kaca yang semakin bertambah. Ini berarti pada tipe kaca bronze tint semakin tebal kaca maka nilai U-value, shade coeffetion dan air flow semakin rendah. Sehingga kebutuhan kapasitas mesin pendingin untuk gedung akan semakin rendah seiring dengan turunnya air flow.

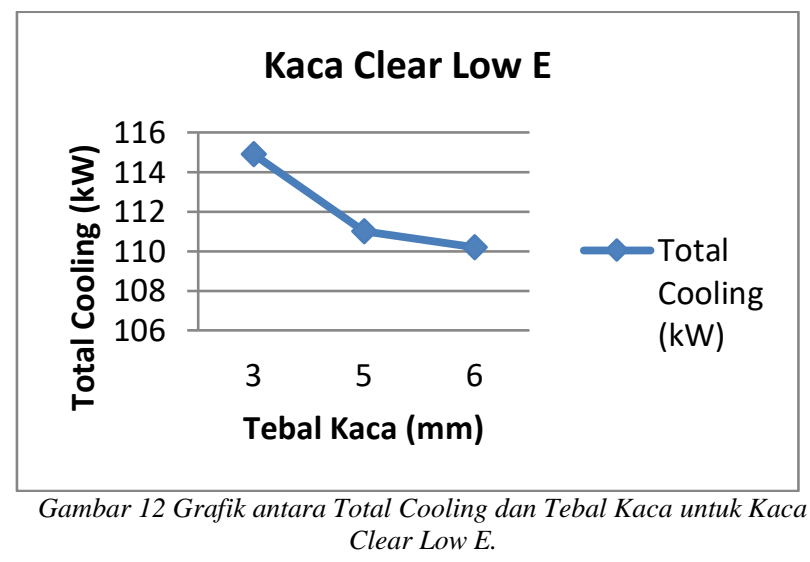

Sesuai grafik di gambar 12 antara total cooling dan tebal kaca untuk kaca clear low e, total cooling akan turun seiring dengan ketebalan kaca yang semakin bertambah. Ini berarti pada tipe kaca clear low e semakin tebal kaca maka nilai U-value, shade coeffetion dan total cooling semakin rendah. Sehingga kebutuhan kapasitas mesin pendingin untuk gedung akan semakin rendah seiring dengan turunnya total cooling.

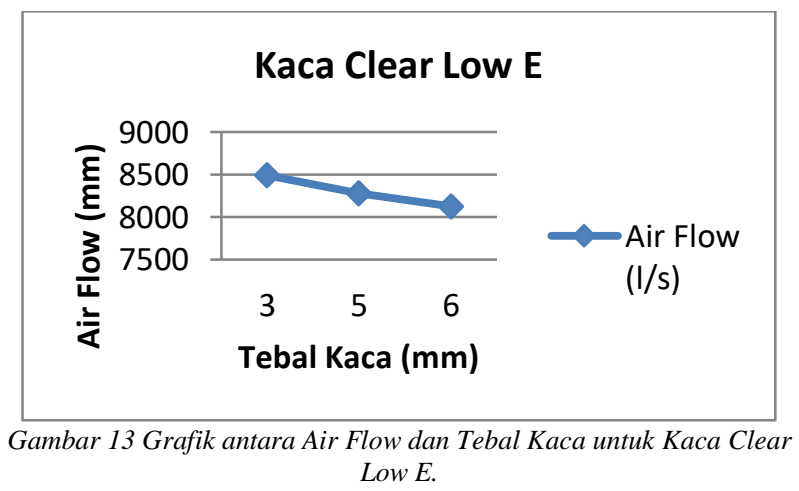

Berdasarkan grafik di gambar 13 antara air flow dan tebal kaca untuk kaca clear low e, air flow akan turun seiring dengan ketebalan kaca yang semakin bertambah. Ini berarti pada tipe kaca clear low e semakin tebal kaca maka nilai U-value, shade coeffetion dan air flow semakin rendah. Sehingga kebutuhan kapasitas mesin pendingin untuk gedung akan semakin rendah seiring dengan turunnya air flow.

\section{Simpulan}

Sesuai data hasil penelitian diatas untuk kedua tipe kaca antara bronze tint dan clear low e didapatkan U-value dan shade coeffetion yang lebih kecil dengan menggunakan tipe kaca bronze tint pada parameter ketebalan kaca yang sama. Sehingga didapatkan perhitungan kapasitas beban pendingin dan air flow yang lebih kecil dengan tipe kaca bronze tint ini. Dengan nilai U-value dan shade coeffetion yang semakin kecil, maka akan didapatkan seleksi mesin pendingin yang mempunyai kapasitas lebih kecil. Dengan seleksi mesin pendingin yang mempunyai kapasitas beban pendingin lebih kecil tersebut untuk dipasang pada sebuah bangunan gedung, sehingga seleksi mesin pendingin yang kecil akan menghemat pemakaian daya listriknya. Karena dengan pemakaian daya listrik yang kecil berarti menghemat anggaran pengeluaran perusahaan dan itu artinya perusahaan mempunyai nkeuntungan yang lebih besar. Akan tetapi beban panas yang mempengaruhi dalam perhitungan beban pendingin tidak hanya timbul dari kaca saja, akan tetapi bias timbul dari banyak hal antara lain dari jumlah orang, beban lampu, arah mata angin, beban peralatan listrik, aktifitas atau kegiatan didalam ruangan dan lainnya.

\section{Kepustakaan}

[1] W. Arismunandar dan H. Saito, Penyegaran Udara, cetakan 4, PT. Pradnya Paramita, Jakarta, 1998.

[2] SNI 03-6572-2001. "Tata Cara Perancangan Sistem Ventilasi dan Pengkondisian Udara pada Bangunan Gedung”, Badan Standarisasi Nasional, 2001.

[3] SNI 6390:2011. "Konservasi Energi Sistem Tata Udara Bangunan Gedung”, Badan Standarisasi Nasional, 2011.

[4] G. H. Purwoko, "Pengaruh Bentuk Dasar dan Orientasi Bangunan Terhadap Beban Energi pada Bangunan Bertingkat di Jakarta", Serat Rupa Journal of Design., vol. 1, pp. 344-352, Mei 2017.

[5] A. B. Yuuwono, "Pengaruh Orientasi Bangunan Terhadap Kemampuan Menahan Panas pada Rumah Tinggal di Perumahan Wonorejo Surakarta," M. T. Tesis, Universitas Diponegoro, Semarang, Indonesia, Desember. 2007.

[6] E. F. Stoecker, J. W. Jones, Refrigerasi dan Pengkondisian Udara, Erlangga, Jakarta, 1989.

[7] G. W. Koestoer, Perpindahan Kalor Untuk Mahasiswa Teknik, Salemba Teknika, Jakarta, 2002.

[8] A. Haryanto, Perpindahan Panas, Innosain, Yogyakarta, 2015.

[9] A. D. Yunus, Perpindahan Panas, Jurusan Teknik Mesin Universitas Darma Persada, Jakarta, 2009.

[10] Saryanto. H, Perpindahan Kalor, Jurusan Teknik Mesin Universitas Mercu Buana, Jakarta, 2012.

[11] Carrier Air Conditioning Company. "Handbook of Air Conditioning System Design”, New York, 1965.

[12] ASHRAE GRP 158. "Infiltrasi and Ventilation", New York, 1999.

[13] ASHRAE Standard 6.2.1-2004. "Ventilation For Acceptable Indoor Air Quality”, New York, 2004. 